\title{
Human Cancer Cell Lines Express a Negative Transcriptional Regulator of the Interferon Regulatory Factor Family of DNA Binding Proteins
}

\author{
EMANUEL PETRICOIN III, ${ }^{1}$ MICHAEL DAVID,${ }^{1,2}$ HUI FANG,${ }^{2}$ PHILIP GRIMLEY, ${ }^{2}$ \\ ANDREW C. LARNER, ${ }^{1,2 *}$ AND SCOTT VANDE POL ${ }^{3 *}$ \\ Division of Cytokine Biology, Center for Biologics Evaluation and Research, ${ }^{1}$ Department of Pathology, \\ Uniformed Services University of the Health Sciences, ${ }^{2}$ and Laboratory of Tumor \\ Virus Biology, National Cancer Institute, ${ }^{3}$ Bethesda, Maryland 20892
}

Received 2 August 1993/Returned for modification 18 September 1993/Accepted 15 November 1993

\begin{abstract}
Members of the interferon regulatory factor (IRF) family of DNA binding transcription factors have roles in growth regulation, antiviral responses, and transcriptional induction of interferon (IFN)-activated early response genes. The IRF family member ISGF3 $\gamma$ is the DNA binding component of IFN-stimulated gene factor 3 (ISGF3), a multicomponent complex responsible for the stimulation of IFN- $\alpha$-responsive genes. IFN- $\alpha$ stimulated formation of ISGF3 and subsequent gene expression can be inhibited by phorbol esters or expression of the adenovirus E1A protein. We have investigated IFN signaling in human malignant tumor cell lines of the lung, colon, ovary, cervix, and hematopoietic organs and found some of these cells to be defective for IFN- $\alpha$-induced formation of ISGF3. In many cases, an inhibitory activity termed transcriptional knockout (TKO) correlated with nonresponsiveness. TKO purified from a human papillomavirus-negative cervical carcinoma cell line has a molecular size of $19 \mathrm{kDa}$. The purified protein interacted with the ISGF3 $\gamma$ component of ISGF3, preventing binding of ISGF3 to DNA. Purified TKO displaced ISGF3 from its DNA binding site in vitro and prevented ISGF3 $\gamma$, IRF-1, and IRF-2 from interacting with the IFN-stimulated response element. Partially purified TKO can also directly interact with ISGF3 $\gamma$ in the absence of DNA. This protein may be involved with the development of malignancies and the inability of IFN to exert its antiproliferative and antiviral effects.
\end{abstract}

The many biological activities of interferons (IFNs) appear to be controlled at least in part by a set of cellular genes which are rapidly induced upon IFN- $\alpha$ or IFN- $\gamma$ binding to specific cell surface receptors. IFN-stimulated gene factors (ISGFs) mediate gene induction by binding to enhancers within the promoters of both IFN- $\alpha$ - and IFN- $\gamma$-induced genes. ISGFs have been characterized, and many of these proteins have been purified and cloned $(5,12,13,25,39)$. Assembly and DNA binding of the ISGF3 complex follows IFN- $\alpha$ activation of a membrane-associated tyrosine phosphatase(s) and tyrosine kinase(s). A subset of the ISGF3 proteins, called ISGF $3 \alpha$, becomes tyrosine phosphorylated $(7,11,15,39)$ and associates with the $48-\mathrm{kDa}$ DNA binding subunit, ISGF3 $\gamma$ (referred to as $48 \mathrm{kDa} \gamma$ to avoid confusion with ISGF3). The complex of ISGF3 $\alpha$ and $48 \mathrm{kDa} \gamma$ completes the assembly of ISGF3, which then translocates to the nucleus and participates in the induction of IFN-activated early response genes.

Several studies indicated that growth promoters such as phorbol esters and interleukin 4, as well as certain proteins from DNA tumor viruses such as adenovirus E1A and the hepatitis B virus polymerase protein, also inhibit IFNinduced gene expression and induction of ISGF3 by IFN- $\alpha$ $(1,10,14,22-24,32)$. In the case of phorbol esters and E1A,

\footnotetext{
* Corresponding authors. Mailing address for Andrew C. Larner: Division of Cytokine Biology, Center for Biologics Evaluation and Research, 8800 Rockville Pike, Bethesda, MD 20892. Phone: (301) 402-0361. Present address for Scott Vande Pol: Department of Pathology, Case Western Reserve University School of Medicine, Cleveland, OH 44106. Phone: (216) 368-1679.
}

decreased formation of ISGF3 does not appear to reflect any inability of IFN- $\alpha$ to modify the ISGF3 $\alpha$ proteins $(1,14,22$, 32). This conclusion is based upon evidence that ISGF3 can be reconstituted by addition of excess $48 \mathrm{kDa}$ in nuclear extracts prepared from cells treated with IFN- $\alpha$ and phorbol ester or extracts from cells which express E1A $(1,14,22$, 32). Deletion of the conserved region 1 domain of E1A abrogated E1A's inhibitory effect on ISGF3 formation. Thus, in both phorbol ester-treated and E1A-expressing cells, the 48kDay subunit of ISGF3 either is not present or is incompetent to permit assembly of ISGF3. Alternatively, an inhibitor which acts upon the $48 \mathrm{kDa}$ protein such that it interacts less effectively with the activated ISGF3 $\alpha$ proteins may be present in phorbol ester-treated cells or cells expressing E1A.

The E6 and E7 proteins encoded by human papillomavirus (HPV) have many biological and structural similarities to adenovirus early proteins $(28,33,37)$. Studies were thus initiated to determine whether expression of the E6 and E7 proteins might modulate IFN signaling. During the course of these investigations, it became apparent that although expression of the E6 and E7 proteins in cervical cancer cell lines correlated with inhibition of IFN-induced gene expression in a manner analogous to that observed with E1A, HPV-negative cervical cancer cell lines and other cancer cell lines also showed defects in IFN- $\alpha$-induced gene expression. In both virally transformed cells and cells from spontaneous human malignancies, IFN- $\alpha$ signaling is inhibited by mechanisms that target the interferon regulatory factor (IRF) family member $48 \mathrm{kDa}$. Using one such HPV-negative cervical cancer cell line, we have purified a protein termed transcriptional knockout (TKO) which specifically inhibited 
the binding to the IFN-stimulated response element (ISRE) of not only the $48 \mathrm{kDa} \gamma$ protein but also IRF-1 and IRF-2.

\section{MATERIALS AND METHODS}

Cells and culture. Human foreskin diploid fibroblasts (GM00468) from the National Institute of General Medical Sciences, HeLa S3 (CCL 2.2), CaSki (CRL 1550), SiHa (HTB 35), C-33A (HTB 31), and HT-3 (HTB 32) cells; a WI-38VA13 subline (CCL 75.1); and FaDu (HTB 43), K562 (CCL 243), NCI-H498 (CCL 254), NCI-H146 (HTB 173), SK-OV3, 293, and MS 751 cells were obtained from the American Type Culture Collection and grown and passaged according to the accompanying recommendations. N592 cells were kindly grown and provided by Herbert Oie (National Cancer Institute).

IFNs and reagents. Recombinant human IFN- $\alpha_{2 a}$ was a generous gift from Hoffmann-LaRoche. Recombinant human IFN- $\gamma$ was provided by Genentech Corp.

Preparation of nuclear and cytoplasmic cell extracts. $\mathrm{Nu}$ clear and cytoplasmic cell extracts were prepared essentially as described elsewhere (32). Selected extracts were alkylated with $10 \mathrm{mM} N$-ethylmaleimide for $20 \mathrm{~min}$ at room temperature followed by quenching with the addition of 15 $\mathrm{mM}$ dithiothreitol at $4^{\circ} \mathrm{C}$.

Electrophoretic mobility shift assays (EMSAs). Gel shift assays were performed with a ${ }^{32} \mathrm{P}$-end-labeled doublestranded synthetic oligonucleotide $(1.0 \mathrm{ng})$ with the sequence 5'GATCCATGCCTCGGGAAAGGGAAACCGAA ACTGAAGCC3' from the ISG15 (ISG with a $15-\mathrm{kDa}$ product) promoter (32). The IFN- $\gamma$ response region (GRR) probe was labeled in the same manner and contained the sequence 5'AGCATGTTTCAAGGATTTGAGATGTATTTCCCAG AAAAG3' (47). The AP1 competitor oligonucleotide was purchased from Promega.

In vitro transcription and translation of $48 \mathrm{kDa \gamma}$, IRF-1, and IRF-2 and formation of the TKO-ISGF3 $\gamma$ complex. The $48 \mathrm{kDa} \gamma$ protein (clone $38-1$ ) (42), the $113-\mathrm{kDa}$ ISGF3 $\alpha$ protein (13), and the full-length IRF-1 (pET-IRF1) and IRF-2 (pET-IRF2) cDNAs (17) were in vitro transcribed and translated with or without $\left.{ }^{35} \mathrm{~S}\right] \mathrm{methionine}$ in rabbit reticulocyte lysate (Promega) according to the manufacturer's recommendation. Two microliters of translated or mock-translated protein was incubated with or without $5 \mathrm{ng}$ of unlabeled ISG15 double-stranded oligonucleotide probe in standard EMSA conditions on ice for $15 \mathrm{~min}$. Five microliters of buffer A $(20 \mathrm{mM} \mathrm{KCl} ; 10 \mathrm{mM}$ HEPES [ $N$-2-hydroxyethylpiperazine- $N^{\prime}$-2-ethanesulfonic acid], $\mathrm{pH} 7 ; 5 \mathrm{mM}$ dithiothreitol; $20 \%$ glycerol) or $5 \mu$ l of a column fraction enriched for TKO activity was added on ice for an additional $15 \mathrm{~min}$ and applied to a $6 \%$ native polyacrylamide gel as described elsewhere (32). Gels were fixed exhaustively to remove unincorporated $\left[{ }^{35} \mathrm{~S}\right] \mathrm{methionine,} \mathrm{dried,} \mathrm{and} \mathrm{exposed} \mathrm{on}$ $\mathrm{X}$-ray film.

Purification of TKO from C-33A cells. C-33A cells were harvested as described above, and extracts were chromatographically separated at $4^{\circ} \mathrm{C}$. Active fractions were assayed by their ability to inhibit the binding of ISGF3 to the ISRE. The following resins were used to purify TKO: (i) heparinSepharose (Pharmacia) with a 0.05 to $0.3 \mathrm{M} \mathrm{NaCl}$ gradient and (ii) hydroxylapatite (Bio-Rad) with a 0 to $0.3 \mathrm{M} \mathrm{Na}_{2} \mathrm{PO}_{4}$ (pH 7.0) elution gradient. The active fractions were dialyzed against $20 \mathrm{mM}$ HEPES (pH 7.0)-20 mM KCl-1 mM dithiothreitol-20\% glycerol (buffer A), and $\left(\mathrm{NH}_{4}\right)_{2} \mathrm{SO}_{4}$ up to $25 \%$ was added to the dialyzed material. This solution was applied to phenyl-Sepharose (Pharmacia), and the flow- through and wash were collected, dialyzed against buffer A, and concentrated on hydroxylapatite. Purified TKO was renatured from sodium dodecyl sulfate (SDS)-13\% polyacrylamide gels as described elsewhere (16).

\section{RESULTS}

Cervical cancer cell lines are defective in IFN-a-induced formation of ISGF3. Several reports have indicated that IFN- $\alpha$-induced gene expression and the formation of ISGF3 are decreased in HPV-positive HeLa S3 cells and that this diminished response can be alleviated by pretreating cells with IFN- $\gamma(2,26)$. It has been hypothesized that insufficient concentrations of $48 \mathrm{kDa}$ in these cells cause decreased formation of ISGF3 and that IFN- $\gamma$ treatment for several hours increases the synthesis of $48 \mathrm{kDa}$ such that formation of ISGF3 is enhanced upon subsequent incubation with IFN- $\alpha(2,26)$. To assess whether this phenomenon was unique to HeLa cells or whether other HPV-positive or -negative cervical carcinoma-derived cell lines exhibited similar patterns of response, ISGF3 formation was assayed by EMSA with a probe corresponding to the ISRE of ISG15 (Fig. 1). Nuclear extracts were prepared from untreated cells or cells treated with either IFN- $\alpha$ for $1 \mathrm{~h}$ or IFN- $\gamma$ for $16 \mathrm{~h}$ followed by IFN- $\alpha$ for $1 \mathrm{~h}$. An EMSA displaying formation of ISGF3 in HPV-positive HeLa cells, HPV-negative C-33A cells, and normal diploid fibroblasts is shown in Fig. 1A. As noted previously $(5,25,32)$, IFN- $\alpha$ induced the formation of ISGF3 in primary fibroblasts (Fig. 1A, lane 1 versus lane 3), whereas HPV-positive HeLa cells showed no induction of ISGF3 unless they were pretreated with IFN- $\gamma$ (lane 5 versus lanes 7 and 8). C-33A cells displayed little if any ISGF3 formation, regardless of whether they were pretreated with IFN- $\gamma$ prior to the addition of IFN- $\alpha$ (Fig. 1A, lanes 9 to 12). These results were consistent with other findings that IFN- $\alpha$ neither induced several IFN-induced RNAs in C-33A cells nor protected them from virus infection (data not shown). ISGF3 formation in several other transformed cell lines was assayed and quantitated relative to formation of ISGF3 in diploid fibroblasts (Fig. 1B). ISGF3 induction was diminished in both HPV-positive (HeLa, SiHa, and CaSki) and -negative (HT-3 and C-33A) cervical cancer cell lines as well as in 293 cells which express E1A. However, there were differences in the responses in that in some lines, pretreatment with IFN- $\gamma$ enhanced IFN- $\alpha$-induced ISGF 3 formation (i.e., in $\mathrm{HeLa}$, SiHa, and 293 cells), whereas in other cell lines, pretreatment with IFN- $\gamma$ had little or no effect (i.e., in HT-3, CaSki, and C-33A cells). Interestingly, the simian virus 40 (SV40)-transformed WI-38VA13 subline (labeled WI38 in Fig. 1B) was relatively sensitive to IFN- $\alpha$ induction of ISGF3. SV40 T antigen shares sequence homology and some functional similarity with the region of adenovirus E1A conserved region 1 (CR1) implicated in preventing ISGF3 formation $(9,19,45,49)$. These results suggested that although E1A and SV40 T antigens have CR1 domains that can complement each other with respect to transformation $(35,48)$, they function differently with respect to IFN-a signaling. The repression of ISGF3 formation by E1A is analogous to the repression of enhancer activity previously mapped to the CR1 domain of E1A, a function not shared with SV40 T antigen $(3,36,40,44)$. Induction of ISG15 RNA by IFN- $\alpha$ in these cell lines paralleled ISGF3 formation (data not shown). Although not shown in Fig. 1B, in no case did IFN- $\gamma$ treatment alone result in induction of ISGF3.

IFN- $\alpha$ signaling is intact in cervical cancer cell lines which display decreased ISGF3 formation. Neither phorbol ester 


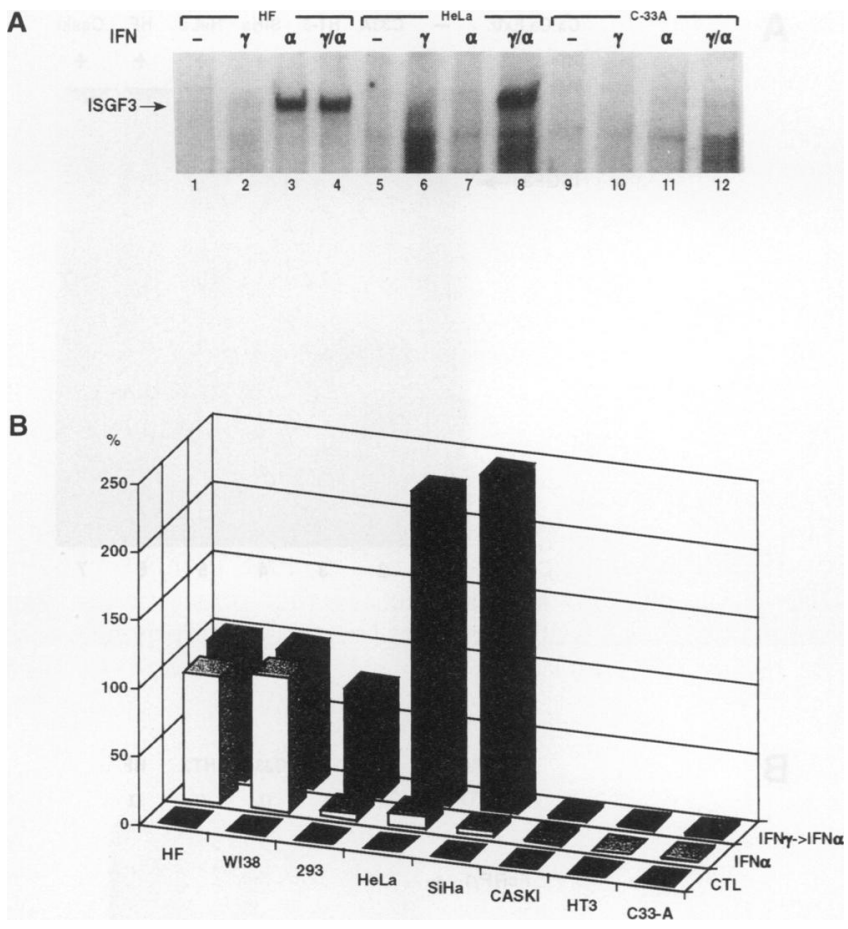

FIG. 1. Cervical cancer cell lines are defective in IFN- $\alpha$-induced ISGF3 formation. (A) Cells were incubated with IFN- $\alpha(500 \mathrm{U} / \mathrm{ml})$ for $1 \mathrm{~h}$ or with IFN- $\gamma(5 \mathrm{ng} / \mathrm{ml})$ for $16 \mathrm{~h}$ followed by IFN- $\alpha$ for $1 \mathrm{~h}$. Nuclear extracts were then prepared as described in Materials and Methods. ISGF3 activity was assayed by gel shift using a ${ }^{32} \mathrm{P}$-endlabeled ISRE probe corresponding to the ISG15 gene. Equal amounts of protein were assayed from each cell line. (B) Basal ISGF3 or ISGF3 levels in response to IFN- $\alpha$ or the combination of IFN- $\alpha$ and IFN- $\gamma$ were quantitated from EMSA gels such as those shown in panel A with an Ambis scanner. Equal amounts of nuclear extract protein were analyzed in each lane. Levels of ISGF3 relative to that in human fibroblasts are shown, with the levels of IFN- $\alpha$ induced ISGF3 from human fibroblasts arbitrarily set at $100 \%$. HPV-positive SiHa, HeLa, and CaSki cervical carcinoma cell lines and HPV-negative HT-3 and C-33A cervical carcinoma cell lines were used. HF, human diploid fibroblasts; 293, adenovirus E1Atransformed human epithelial cells; WI38, WI-38VA13 subline.

nor adenovirus E1A appears to cause a defect in IFN- $\alpha$ induced modification of the ISGF3 $\alpha$ proteins $(1,14,22,32)$. In fact, in vitro addition of extracts which contained excess $48 \mathrm{kDa}$ protein to extracts from IFN- $\alpha$-treated cells which express E1A or which have been treated with phorbol myristate acetate restored formation of ISGF3 $(1,14,22,32)$. In order to see whether the virus-negative cell line C-33A was similar to phorbol ester-treated or E1A-expressing cells, experiments were done to determine whether IFN- $\alpha$-induced modification of the $\alpha$ peptides was intact. Similar to the results observed with phorbol ester-treated cells and those expressing E1A, addition of excess in vitro-translated $48 \mathrm{kDa} \gamma$ protein also reconstituted ISGF3 formation in nuclear extracts prepared from IFN- $\alpha$-treated C-33A cells (Fig. $2 \mathrm{~A}$, lane 8) to levels comparable to those in diploid fibroblasts (lane 5). The effects of the addition of the $48 \mathrm{kDa}$ protein were specific in that the addition of a nonspecific control translation protein (the $113-\mathrm{kDa}$ protein of ISGF3) did not reconstitute the complex (compare lanes 5 and 6 in Fig. 2A). Similar results were seen with extracts of HeLa, $\mathrm{SiHa}, \mathrm{CaSki}$, and HT-3 cells after addition of in vitro-

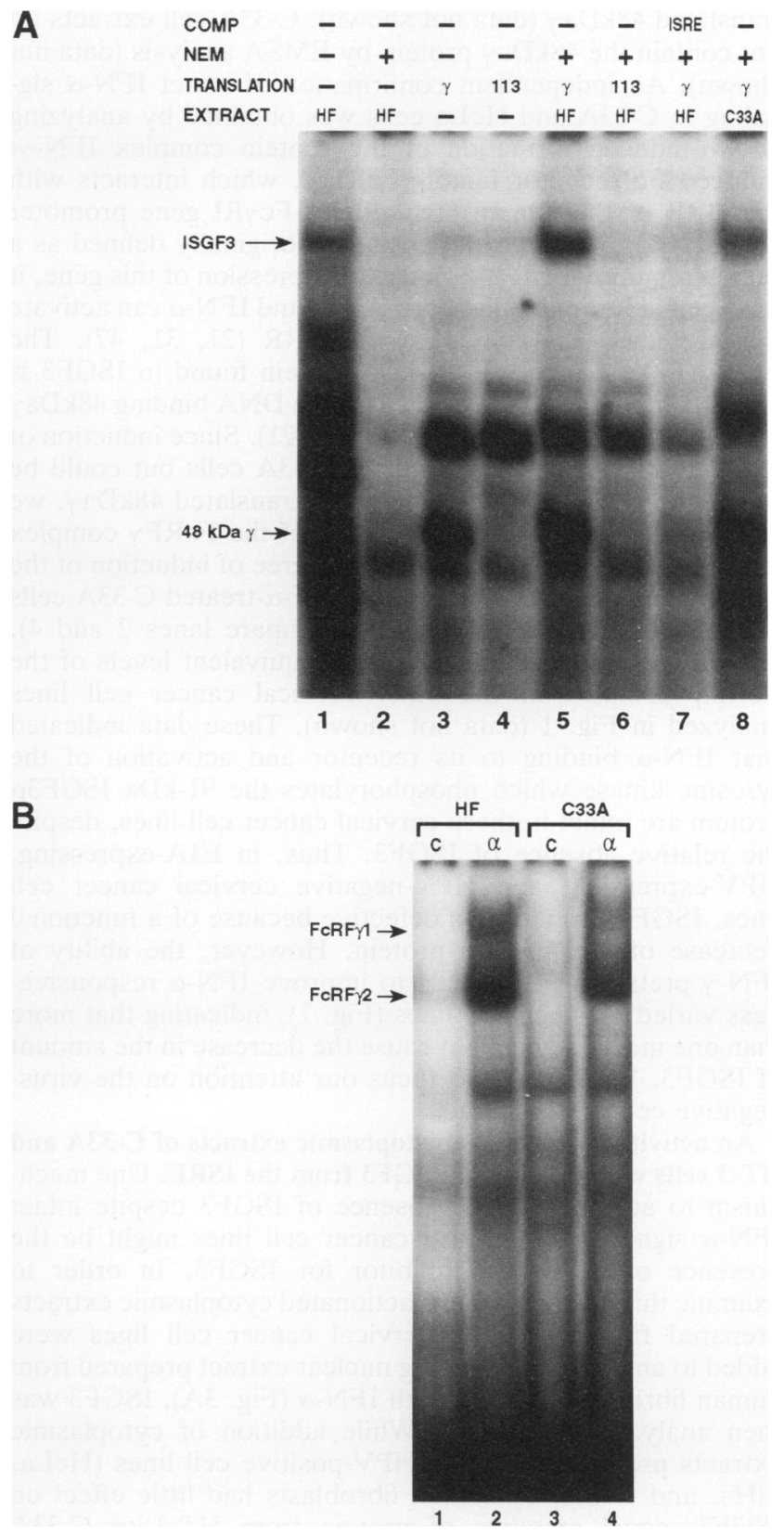

FIG. 2. IFN- $\alpha$ signaling is intact, despite diminished ISGF3 formation, in HPV-positive and -negative cervical carcinoma cell lines. (A) The $48 \mathrm{kDa}$ protein reconstitutes ISGF3 in IFN- $\alpha$ stimulated C-33A cervical cancer cells. ISGF3 was assayed by EMSA by using a ${ }^{32}$ P-end-labeled ISRE probe after the addition of in vitro-translated $48 \mathrm{kDa} \gamma$ peptide $(\gamma)$ (lanes $3,5,7$, and 8 ) or $113-\mathrm{kDa}$ alpha peptide (113) (lanes 4 and 6). The 113-kDa protein, which is a component of ISGF3, was used as a negative control. Competitor (COMP) (50-fold molar excess) ISG15 oligonucleotide was added to lane 7 to demonstrate specificity. $N$-ethylmaleimide (NEM) was used to inactivate endogenous $48 \mathrm{kDa}$ in nuclear extracts as indicated in the figure. HF, human diploid fibroblasts. (B) C-33A cells respond to IFN- $\alpha$, as measured by the formation of the FcRF $\gamma$ DNA binding complex. IFN- $\alpha$ signaling was measured by the capacity to activate the FcRF $\gamma$ complex in an EMSA utilizing a ${ }^{32} \mathrm{P}$-end-labeled GRR probe from the FcRy promoter. Cells were treated with IFN- $\alpha$ for $1 \mathrm{~h}$ prior to harvest and preparation of nuclear extracts. HF, human diploid fibroblasts; C, untreated cells; $\alpha$, cells treated with IFN- $\alpha$. 
translated $48 \mathrm{kDa}$ (data not shown). C-33A cell extracts do not contain the $48 \mathrm{kDa}$ protein by EMSA analysis (data not shown). An independent confirmation of intact IFN- $\alpha$ signaling in C-33A and HeLa cells was obtained by analyzing IFN- $\alpha$-induced formation of the protein complex IFN- $\gamma$ induced Fc receptor factor (FcRF $\gamma$ ), which interacts with the GRR of the human high-affinity Fc $\gamma$ RI gene promoter $(21,31,47)$. Although the GRR was originally defined as a region required for IFN- $\gamma$-induced expression of this gene, it has been determined that both IFN- $\gamma$ and IFN- $\alpha$ can activate the protein(s) that binds to the GRR $(21,31,47)$. The tyrosine-phosphorylated $91-\mathrm{kDa}$ protein found in ISGF3 is also a component of FCRF $\gamma$, while the DNA binding 48kDa $\gamma$ protein is not present in the complex (21). Since induction of ISGF3 was completely absent in C-33A cells but could be reconstituted by addition of in vitro-translated $48 \mathrm{kDa} \gamma$, we examined IFN- $\alpha$-induced formation of the FCRF $\gamma$ complex in C-33A cells (Fig. 2B). A similar degree of induction of the FcRF $\gamma$ complex was observed in IFN- $\alpha$-treated C-33A cells and diploid fibroblasts (Fig. 2B, compare lanes 2 and 4). IFN- $\alpha$ also induced approximately equivalent levels of the FcRF $\gamma$ complex in the other cervical cancer cell lines analyzed in Fig. 1 (data not shown). These data indicated that IFN- $\alpha$ binding to its receptor and activation of the tyrosine kinase which phosphorylates the $91-\mathrm{kDa}$ ISGF3 $\alpha$ protein are intact in these cervical cancer cell lines, despite the relative absence of ISGF3. Thus, in E1A-expressing, HPV-expressing, and HPV-negative cervical cancer cell lines, ISGF3 formation is defective because of a functional decrease of the $48 \mathrm{kDa}$ protein. However, the ability of IFN- $\gamma$ pretreatment of cells to improve IFN- $\alpha$ responsiveness varied between cell lines (Fig. 1), indicating that more than one mechanism might cause the decrease in the amount of ISGF3. We decided to focus our attention on the virusnegative cell line C-33A.

An activity is present in cytoplasmic extracts of C-33A and HT-3 cells which displaces ISGF3 from the ISRE. One mechanism to account for the absence of ISGF3 despite intact IFN- $\alpha$ signaling in cervical cancer cell lines might be the presence of a specific inhibitor for ISGF3. In order to examine this possibility, unfractionated cytoplasmic extracts prepared from untreated cervical cancer cell lines were added to an ISGF3-containing nuclear extract prepared from human fibroblasts treated with IFN- $\alpha$ (Fig. 3A). ISGF3 was then analyzed by EMSA. While addition of cytoplasmic extracts prepared from the HPV-positive cell lines (HeLa, $\mathrm{SiHa}$, and CaSki) or human fibroblasts had little effect on ISGF3, equal amounts of protein from HT-3 or C-33A cytoplasmic extracts caused a dramatic decrease $(60 \%$ to greater than 90\%) in the amount of detectable ISGF3 (Fig. $3 \mathrm{~A}$, compare lanes 2 and 3 with lanes 4 to 7). Initial characterization of this TKO indicated that it completely displaced ISGF3 that had been prebound to DNA in less than $1 \mathrm{~min}$ at $4^{\circ} \mathrm{C}$. Further characterization of TKO has shown it to be heat labile and protease sensitive, but it was not inhibited by $N$-ethylmaleimide, RNases, or protease or phosphatase inhibitors (vanadate, NaF, okadaic acid, calyculin A, or levamisol), suggesting that it is unlikely to be a phosphatase, kinase, or protease. TKO also displaced affinity-purified ISGF3 interaction with the ISRE (data not shown). Interestingly, extracts from 293 cells which constitutively express the adenovirus E1A protein showed no disruption of ISGF3 from the DNA probe (data not shown). These results not only reinforced phenotypic differences between these cell lines with regard to their inhibition of IFN- $\alpha$-induced ISGF3 formation but also provided direct
A

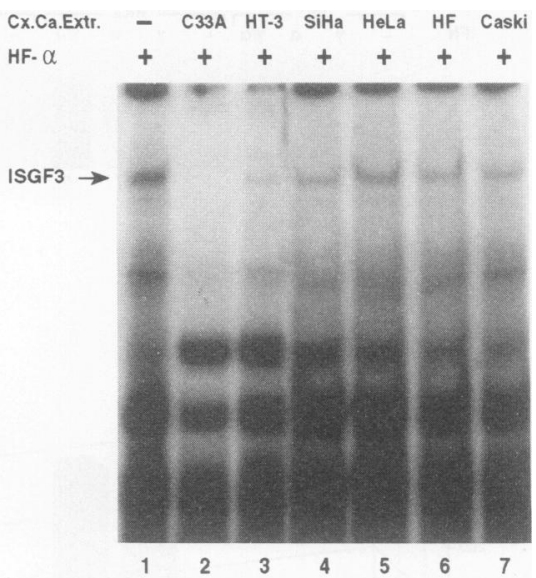

B

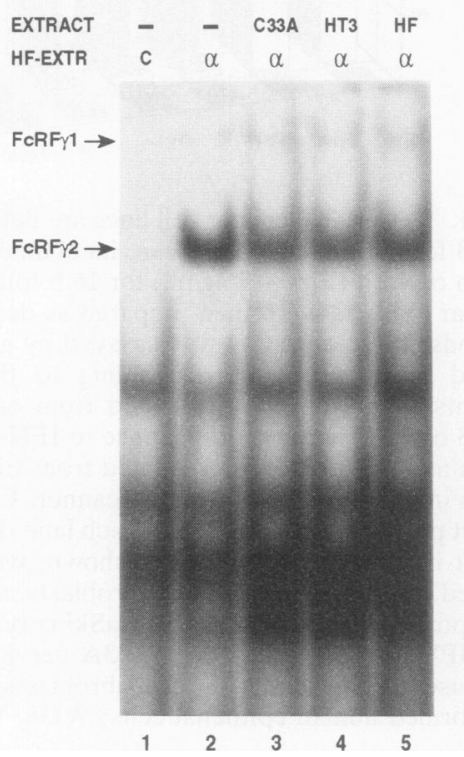

FIG. 3. An activity which prevents ISGF3, but not FcRFy, binding to DNA is present in cytoplasmic extracts of C-33A and HT-3 cells. (A) Cytoplasmic extracts (Cx.Ca.Extr.) $(10 \mu \mathrm{g})$ prepared from C-33A (lane 2), HT-3 (lane 3), SiHa (lane 4), and HeLa (lane 5) cells; human fibroblasts (HF) (lane 6); and CaSki cells (lane 7) were incubated $\left(4^{\circ} \mathrm{C}\right)$ with a nuclear extract containing ISGF3 prepared from human fibroblasts treated with IFN- $\alpha$ for $1 \mathrm{~h}(\mathrm{HF}-\alpha)$ EMSAs with an ISRE probe were used to measure ISGF3 formation. (B) The extracts used in the experiment described in the legend to panel $A$ were analyzed for the formation of FcRF $\gamma$. Lane 1 contains nuclear extract prepared from untreated human fibroblasts $(C)$, and lanes 2 through 5 contain nuclear extracts prepared from human fibroblasts incubated with IFN- $\alpha(\alpha)$ for $1 \mathrm{~h}$. Cytoplasmic extracts from C-33A cells, HT-3 cells, and human fibroblasts were added in lanes 3,4 , and 5, respectively. HF, human fibroblasts; EXTR, extract.

evidence of the presence of a cellular factor which can displace prebound ISGF3 from the ISRE.

In order to characterize the specificity of TKO in C-33A and HT-3 cells, we took advantage of the fact that the IFN-induced FCRF $\gamma$ complex contains the $91-\mathrm{kDa}$ protein but not $48 \mathrm{kDa}$ or the $113-\mathrm{kDa}$ protein (data not shown). C-33A or HT-3 cytoplasmic extracts were added to human 
fibroblast nuclear extracts prepared from IFN- $\alpha$-treated cells, and FcRF $\gamma$ complexes instead of ISGF3 were analyzed with the GRR probe. It can be seen (Fig. 3B) that C-33A and HT-3 cytoplasmic extracts that decreased ISGF3 levels in the experiment described in Fig. 3A did not affect FcRF $\gamma$ in that described in Fig. 3B. This result indicated both that TKO present in C-33A and HT-3 cells was specific for the ISGF3 transcription complex and that TKO did not exert its activity by interacting with the $91-\mathrm{kDa}$ protein of ISGF3.

TKO disrupts binding of the 48kDay protein, IRF-1, and IRF-2 to the ISRE. The data presented in Fig. 3 suggested that TKO might inhibit the $48 \mathrm{kDa}$ component of ISGF3 from binding to the ISRE or associating with the ISGF3a proteins. To examine the former possibility, 48kDay was tested for its ability to interact with the ISRE in the presence or absence of TKO (Fig. 4A). As described previously (41), $48 \mathrm{kDa} \gamma$ translated in reticulocyte lysates specifically binds to the ISRE and was displaced by the unlabeled ISRE oligonucleotide (Fig. 4A, lane 1 versus lane 2) but not by an unlabeled oligonucleotide corresponding to an AP1 binding site (lane 1 versus lane 3 ). Addition of partially purified TKO prepared from C-33A cells to the binding reaction mixture inhibited $48 \mathrm{kDa} \gamma$ binding to the ISRE in a dose-dependent manner (Fig. 4A, lanes 5 to 9), while an inactive fraction from the heparin-Sepharose column, which contained an equal amount of protein, was without effect (compare lanes 4 and 9).

The $48 \mathrm{kDa}$ protein is a member of a family of DNA binding proteins which recognize the core sequence of the ISRE (42). Other members of this family include IRF-1, IRF-2, and ICSBP $(8,17,27,34)$. IRF-1 (ISGF2) and IRF-2 bind specifically to the ISRE of IFN-stimulated genes or to the PRD1 regulatory domain of the IFN- $\beta$ gene, where they function as either positive (IRF-1) or negative (IRF-2) regulators of IFN- $\beta$ transcription (17). IRF-1 has negative growth effects and has been found to be deleted in some human leukemias $(18,46)$. IRF-2 antagonizes the actions of IRF-1 and acts as an oncogene when overexpressed in NIH 3T3 cells (18). Although ICSBP has not been shown to directly interact with the ISRE by EMSA, expression of the protein inhibited IFN- $\alpha$-induced gene transcription (29). EMSAs were done to determine whether partially purified TKO influenced the binding of in vitro-translated IRF-1 or IRF-2 to the ISRE (Fig. 4B and C). In a manner analogous to its inhibitory effects on $48 \mathrm{kDa} \gamma$ binding to the ISRE, TKO clearly inhibited binding of both IRF-1 (Fig. 4B) and IRF-2 (Fig. 4C) to the ISRE. C-33A extracts also abrogated binding of IRF-1 and IRF-2 to the PRD1 oligonucleotide and the enhancer element within the IFN- $\beta$ promoter that binds IRF-1 and IRF-2 (17) (data not shown). As shown in Fig. 4 there were no significant differences in the potency of the inhibitory effects of crude or partially purified TKO on binding of IRF-1, IRF-2, and the $48 \mathrm{kDa} \gamma$ protein to the ISRE.

Purified TKO consists of a single protein of $19 \mathrm{kDa}$. TKO activity was purified approximately 5,000 -fold from extracts of C-33A cells by a combination of heparin-Sepharose, hydroxylapatite, and phenyl-Sepharose column chromatography. To identify the polypeptide associated with TKO activity, the most highly purified preparations were resolved by SDS-polyacrylamide gel electrophoresis (PAGE) and silver staining was performed (Fig. 5A). A lane adjacent to that which was silver stained was cut into slices, and proteins were eluted, renatured, and tested for TKO activity upon ISGF3 (Fig. 5B). TKO was recovered only from fraction 6 , which contained a single species of $19 \mathrm{kDa}$. (This

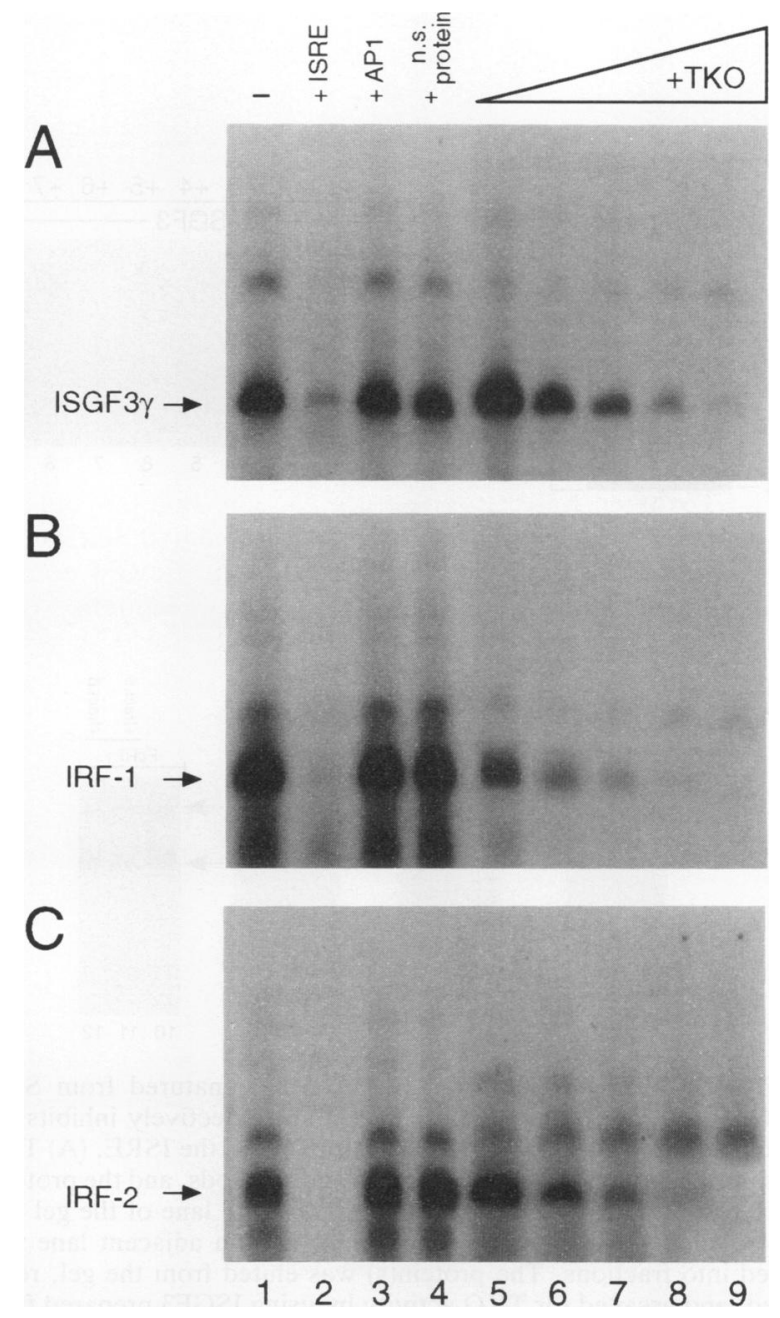

FIG. 4. TKO prevents the binding of the $48 \mathrm{kDa}$ protein, IRF-1, and IRF-2 to the ISRE. The $48 \mathrm{kDa}$ protein (A), IRF-1 (B), and IRF-2 (C) were in vitro transcribed and translated as described in the legend to Fig. 2. The binding of these proteins to the ISRE was assayed by EMSA with the ISRE probe (lanes 1 ). Specificity of the complexes was demonstrated by the fact that unlabeled ISRE ( 25 molar excess) displaced the binding (lanes 2) while an oligonucleotide corresponding to AP1 did not affect binding (lanes 3 ). Increasing concentrations of TKO activity, which was partially purified on heparin-Sepharose, were added to lanes 5 to 9 , while an amount of protein equivalent to that used in lanes 9 from a column fraction without TKO activity was added to lanes 4 . The identity of the more slowly migrating complexes which migrate above 48kDa $\gamma$, IRF-1, and IRF-2 is unknown, but specificity is shown by the fact that the complexes are competed for by the unlabeled ISRE but not by AP1. Interestingly, TKO displaced the complexes seen in panels A and B. n.s., nonspecific heparin-Sepharose fraction without TKO activity.

particular protein stained a light tan color and therefore appears to be white when photographed.) Other slices from the gel contained no TKO activity. Fraction 6 , which contained TKO, and an adjacent slice from the gel were also tested for activity with regard to inhibition of binding of in vitro-translated 48kDay, IRF-1, and IRF-2 to the ISRE and FcRFy to the GRR (Fig. 5B). While the TKO activity associated with fraction 6 inhibited binding of 48kDar, IRF-1, and IRF-2 to the ISRE, it had no effect on the binding of FcRF $y$ to the GRR (Fig. 5B, compare lanes 11 and 12 with 

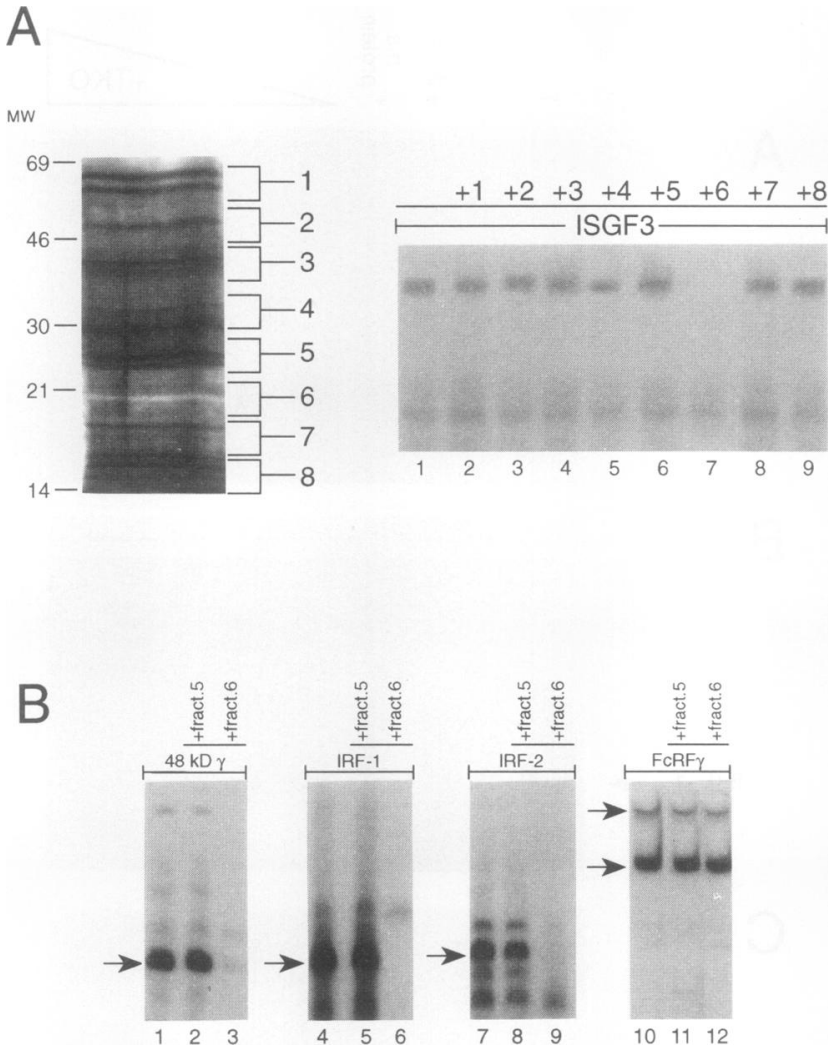

FIG. 5. TKO purified from C-33A cells renatured from SDSPAGE has a molecular size of $19 \mathrm{kDa}$ and selectively inhibits the binding of ISGF3, 48kDay, IRF-1, and IRF-2 to the ISRE. (A) TKO was purified as described in Materials and Methods, and the proteins were resolved on an SDS-13\% PAGE gel. One lane of the gel was subjected to silver staining (left panel), and an adjacent lane was sliced into fractions. The protein(s) was eluted from the gel, renatured, and assayed for TKO activity by using ISGF3 prepared from IFN- $\alpha$-treated human fibroblasts (right panel) by using a ${ }^{32} \mathrm{P}$-endlabeled ISRE probe. The fraction numbers are indicated on the right and above the EMSA gel in the left and right panels, respectively. Molecular weight (MW) (left panel) is given in thousands. (B) Fraction 6, which inhibited ISGF3 binding to the ISRE, and fraction 5 , which was inactive, were tested for TKO activity by using in vitro-translated $48 \mathrm{kDa \gamma}$ (lanes 1 to 3 ), IRF-1 (lanes 4 to 6), or IRF-2 (lanes 7 to 9). As a negative control, fractions 5 and 6 were assayed for their ability to inhibit the formation of the IFN- $\alpha$-induced FcRF $\gamma$ to the GRR (lanes 10 to 12). The arrows indicate the specific complexes formed by binding of the $48 \mathrm{kDa} \gamma$, IRF-1, or IRF-2 protein with the ISRE probe.

lanes $2,3,5,6,8$, and 9). This pattern of TKO activity was the same as that of the crude C-33A cytoplasmic extract shown in Fig. 3 and the partially purified TKO activity shown in Fig. 4.

TKO binds to the 48kDay protein. Because TKO did not appear to bind to the ISRE when assayed by EMSA (data not shown), experiments were performed to determine whether it could interact directly with the $48 \mathrm{kDa}$ protein. The 48kDay protein was in vitro translated with $\left[{ }^{35}\right.$ S]methionine and incubated with either human fibroblast extracts or partially purified C-33A extracts enriched for TKO activity (Fig. 6A). Formation of 48kDay-TKO complexes was then assessed by using nondenaturing acrylamide gels under conditions identical to those used in the EMSA. The 48kDay protein did not enter the gel in the absence of the unlabeled ISRE oligonucleotide (Fig. 6A, lane 1). (The reason[s] that $48 \mathrm{kDa}$ does not enter the gel is not apparent.) Addition of the ISRE permitted the formation of a complex (Fig. 6A, lane 2) which was not altered in the presence of human fibroblast extract (lane 3). However, in the presence of TKO, the retarded $48 \mathrm{kDa}$ protein-ISRE complex disappeared and a new more slowly migrating and diffuse band formed (Fig. 6A, lane 4). The formation of this complex did not require the presence of the ISRE oligonucleotide, since the complex was seen with the addition of TKO in the absence of DNA (Fig. 6A, compare lanes 4 and 7). Analysis of the ${ }^{35} \mathrm{~S}$-labeled $48 \mathrm{kDa \gamma}$ protein on SDS-polyacrylamide gels after extended incubation with TKO showed that the $48 \mathrm{kDa}$ y protein was not degraded (data not shown). To ensure that the $48 \mathrm{kDa}$-TKO complex which was present in the gel shown in Fig. 6A (lane 7) correlated with the ability to inhibit binding of the $48 \mathrm{kDa}$ protein to the ISRE, crude cytoplasmic C-33A extracts were fractionated on a heparinSepharose column. Fractions which contained TKO activity and side fractions which were devoid of activity were assayed in parallel both for the ability to disrupt the $48 \mathrm{kDa}$ ISRE complex (Fig. 6B, upper panel) and for the ability to form a TKO-48kDay complex in the absence of DNA (lower panel). There was a complete correlation between fractions which inhibited binding of the $48 \mathrm{kDa}$ protein to the ISRE and the formation of the $48 \mathrm{kDa}$-TKO complex. This result emphasized that TKO binding to the $48 \mathrm{kDa}$ protein is at least one mechanism by which TKO disrupts formation of the ISGF3 transcription complex.

Several human cancer cell lines contain a TKO activity which disrupts binding of the 48kDay protein to the ISRE. Although our initial studies focused on characterization and purification of TKO from the C-33A cervical cancer cell line, many other IFN-resistant cell lines derived from human cancers have been reported (4). To determine whether extracts from any other neoplastic cell lines might also contain analogous TKO activity, cytoplasmic extracts were prepared from a variety of cell lines derived from human cancers. Cytoplasmic extracts prepared from these cell lines were then added to $48 \mathrm{kDa}$ and assayed for their ability to inhibit binding of $48 \mathrm{kDa} \gamma$ to the ISRE, and quantitation of TKO activity from the extracts prepared from the various cell lines was performed (Fig. 7). Although some of these cell lines clearly contained no TKO activity (Fig. 7, columns 5 and 6), others significantly inhibited binding of $48 \mathrm{kDa} y$ to the ISRE (columns 7 to 12). Like C-33A cells, the cell lines which contained TKO activity also showed both decreased endogenous ISGF3 formation and normal FcRF $\gamma$ formation after IFN- $\alpha$ treatment (Fig. 1 and 2) (data not shown). Whether the TKO activity observed in these human cancer cell lines is identical to that purified from C-33A cells remains to be determined.

\section{DISCUSSION}

IFN-induced signal transduction has been recently clarified by a number of different experimental approaches (5-7, $11,15,25,38)$. Although IFNs are well-described inhibitors of cell growth, the specific mechanisms by which tumor promoters, the expression of viral oncogenes, and cell transformation modulate IFN signaling remain poorly defined. Previous reports have indicated that phorbol esters, interleukin 4, expression of adenovirus E1A, or hepatitis B virus polymerase protein can all inhibit IFN- $\alpha$-induced ISGF3 formation $(1,10,14,22-24,32)$. The inhibitory effects 
A

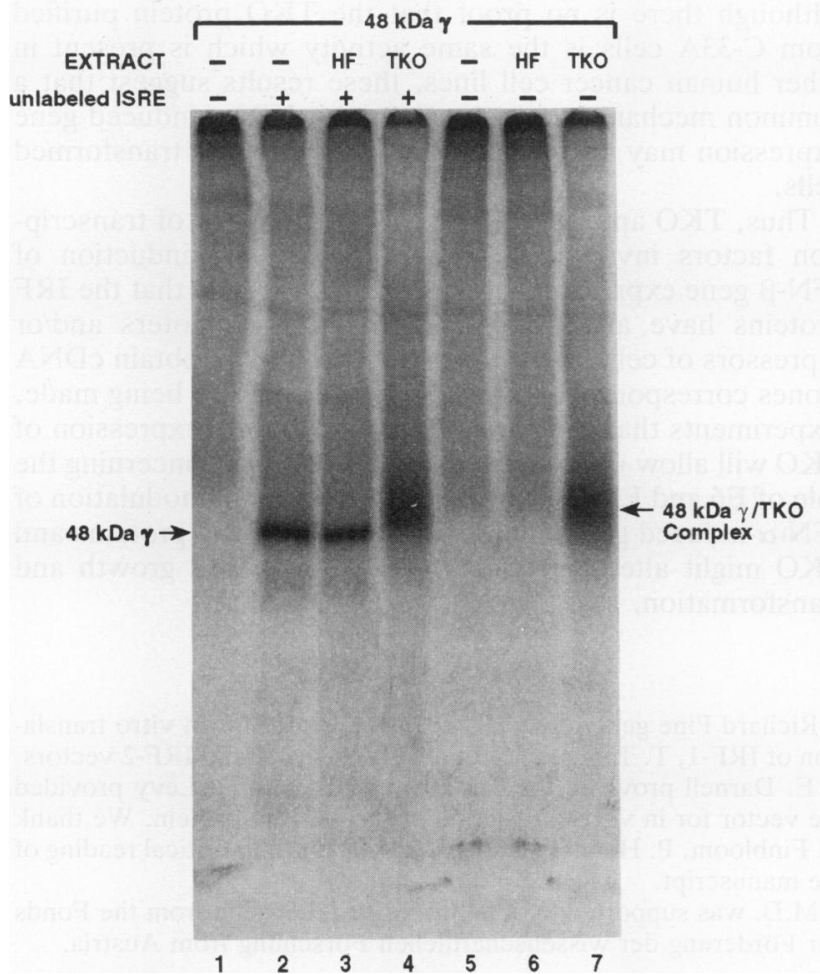

B
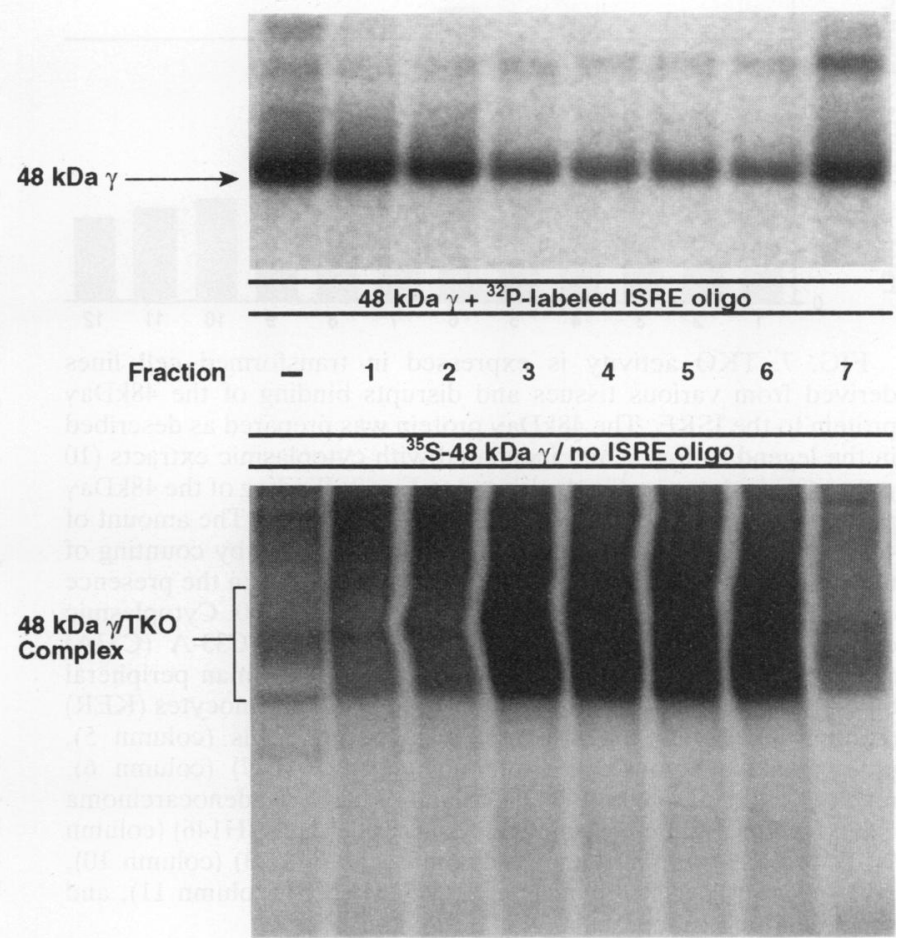

FIG. 6. Evidence of a direct interaction between TKO and the 48kDay protein. (A) A new complex is detected when a fraction containing TKO is incubated with ${ }^{35} \mathrm{~S}$-labeled $48 \mathrm{kDa}$ protein. In vitro-translated ${ }^{35} \mathrm{~S}$-labeled $48 \mathrm{kDa} \gamma$ protein was incubated at $4^{\circ} \mathrm{C}$ with (lanes 2 to 4 ) or without (lanes 1 and 5 to 7) unlabeled ISRE oligonucleotide. The incubation mixtures were then subjected to nondenaturing PAGE as described in Materials and Methods. Lanes: $1,{ }^{35} \mathrm{~S}$-labeled $48 \mathrm{kDa}$ protein; 2 ; same as lane 1 with unlabeled ISRE; 3 , same as lane 2 with 10 $\mu \mathrm{g}$ of cytoplasmic extract prepared from human diploid fibroblasts (HF); 4, same as lane 2 with partially purified TKO, after heparin-Sepharose chromatography. Lanes 5, 6, and 7 are the same as lanes 2, 3, and 4 except that no ISRE oligonucleotide was included in the incubations. (B) TKO activity as assayed by disruption of binding of ${ }^{35} \mathrm{~S}$-labeled $48 \mathrm{kDa} \gamma$ protein to the ISRE cofractionates with the 48kDay-TKO complex as assayed in the experiment shown in Fig. 5A. Fractions (6 of 25$)$ from heparin-Sepharose chromatography which contained TKO as assayed by disruption of binding of ${ }^{35} \mathrm{~S}$-labeled $48 \mathrm{kDa}$ protein to the ISRE and adjacent side fractions (upper panel) were simultaneously assayed for formation of the 48kDay-TKO complex (lower panel).

of E1A and phorbol esters on ISGF3 activation were reversed in vitro by the addition of excess amounts of the 48kDay DNA binding component of the ISGF3 transcription complex $(1,10,14,22,32)$. This implied that both E1A and phorbol esters target the IRF family member $48 \mathrm{kDa}$ or that absent or modified $48 \mathrm{kDa}$ is a marker for these effectors. In this study, we found that HPV expression in HeLa, $\mathrm{SiHa}$, and CaSki cells correlated with decreased IFN- $\alpha$ responsiveness, and, as shown earlier with $\mathrm{HeLa}$ cells $(2,25)$, IFN- $\alpha$ unresponsiveness could be overcome in vitro by the addition of excess 48kDay (Fig. 1) or in vivo by treatment of cells with IFN- $\gamma$ prior to the addition of IFN- $\alpha$. Surprisingly, HPV-negative cervical cancer cell lines as well as other human cancer cell lines were also found to be defective for ISGF3 formation (Fig. 2A and 7).

The defects in ISGF3 formation seen in E1A- or HPVexpressing cells and the human malignancies examined in this study were all due to defective and/or deficient $48 \mathrm{kDa}$. Three experimental approaches suggested this to be the case. (i) Addition of in vitro-translated $48 \mathrm{kDa}$ to nuclear extracts prepared from the cervical cancer cell lines after IFN- $\alpha$ treatment reconstituted ISGF3 formation to a much higher level (e.g., compare Fig. 1A, lane 11, with Fig. 2A, lane 8). (ii) IFN- $\alpha$-induced formation of the FcRF $\gamma$ complexes (which do not contain $48 \mathrm{kDa}$ protein) was the same in all cervical cancer and transformed cell lines as it was in diploid fibroblasts (Fig. 2B). This result suggested intact tyrosine phosphorylation of the $91-\mathrm{kDa}$ subunit of ISGF3, as IFN-induced tyrosine phosphorylation of the 91-kDa protein is also required to form FCRFy $(20,30,31)$. (iii) The TKO activity present in C-33A and HT-3 cells had no effect on the assembly of the FcRFy complexes (Fig. 3A).

It should be noted that the defects of ISGF3 formation characterized in the malignant cell lines here are clearly different from the mutation in the cell line described by Velazquez et al. (43), which lacks the tyrosine kinase Tyk2 required to activate the ISGF3 $\alpha$ proteins. While it is evident from this study that a cellular competitor(s) exists in many cancer cell lines derived from cervical and other malignancies, at the moment it is uncertain whether mutations in the IFN- $\alpha$ receptor, Tyk 2 , or any of the ISGF 3 components may be also directly or indirectly related to transformation.

Although all these cell lines are functionally deficient in $48 \mathrm{kDa}$ protein, they do demonstrate phenotypic differences. Whereas in some HPV- or E1A-expressing cells, treatment with IFN- $\gamma$ prior to addition of IFN- $\alpha$ enhanced 
C33A HF LYM KER HTB9 FADU K562 H498 H146 OVC3 MS N592

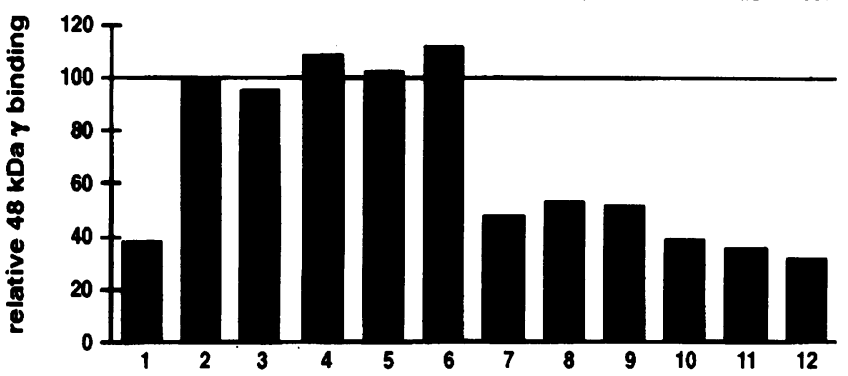

FIG. 7. TKO activity is expressed in transformed cell lines derived from various tissues and disrupts binding of the $48 \mathrm{kDa}$ protein to the ISRE. The $48 \mathrm{kDa}$ protein was prepared as described in the legend to Fig. 2 and incubated with cytoplasmic extracts $(10$ $\mu \mathrm{g}$ ) at $4^{\circ} \mathrm{C}$ as described in the legend to Fig. 3. Binding of the $48 \mathrm{kDa} \gamma$ protein to an ISRE probe was analyzed by gel shift. The amount of $48 \mathrm{kDa}$ protein bound to the ISRE was quantitated by counting of the $48 \mathrm{kDa}$ band. The amount of binding of $48 \mathrm{kDa} \gamma$ in the presence of the HF extract was given an arbitrary value of 100. Cytoplasmic extracts added to the 48kDay protein included C33-A (C33A) (column 1), human fibroblasts (HF) (column 2), human peripheral blood lymphocytes (LYM) (column 3), human keratinocytes (KER) (column 4), HTB9 transitional-cell carcinoma cells (column 5), pharyngeal squamous-cell carcinoma cells (FADU) (column 6), myeloid leukemia cells (K562) (column 7), colon adenocarcinoma cells (H498) (column 8), small-cell lung cancer cells (H146) (column 9), OVCAR-3 ovarian adenocarcinoma cells (OVC3) (column 10), HPV-negative cervical cancer cells MS751 (MS) (column 11), and small-cell lung cancer cells (N592) (column 12).

ISGF3 formation, the effects of IFN- $\gamma$ were not significant in the HPV-negative cervical cancer cell lines. The reason why treatment of C33-A, HT-3, or CaSki cells with IFN- $\alpha$ after prior exposure to IFN- $\gamma$ did not lead to formation of ISGF3 (Fig. 2B) is not understood. The fact that cytoplasmic extracts from C-33A and HT-3 cells, but not from HPV- or E1A-positive cells, disrupted ISGF3 activity reinforced the idea that distinct phenotypes can be defined when IFN- $\alpha$ induced gene expression is depressed (Fig. 3A). The mechanism(s) by which expression of E1A (or possibly E6 and E7) renders $48 \mathrm{kDa} \gamma$ protein less capable of interacting with the ISGF3 $\alpha$ proteins is not clear. However, it is clear that several HPV-negative cervical cancer cell lines as well as transformed cell lines derived from a wide variety of neoplasms contain an activity (TKO) which disrupts ISGF3. This activity is not present in normal cells such as fibroblasts, lymphocytes, and keratinocytes (Fig. 3A and 7).

Because the addition of excess $48 \mathrm{kDa}$ restored ISGF 3 in C-33A cell extracts (Fig. 2A), it seemed likely that TKO acted upon the $48 \mathrm{kDa} y$ subunit of ISGF3 and thus inhibited IFN- $\alpha$-induced gene expression. To investigate this possibility, we purified TKO from C-33A cellular extracts. Using either highly purified preparations of TKO or the $19-\mathrm{kDa}$ protein renatured from SDS-PAGE, we demonstrated that TKO prevented binding not only of $48 \mathrm{kDa}$ but also of IRF-1 and IRF-2 to the ISRE. Given the high degree of sequence homology among the DNA binding domains of the IRF family members, this result is not surprising (42). The biological consequences of TKO expression with regard to the functional effects of IRF-1 and IRF-2 are under investigation. In addition, by using highly enriched C-33A-derived TKO, it was possible to demonstrate a direct interaction with in vitro-translated $48 \mathrm{kDa}$ (Fig. 6). Other cancer cell lines which contained TKO activity as assayed by disruption of $48 \mathrm{kDa}$ binding to the ISRE also inhibited binding of IRF-1 and IRF-2 to the same probe (data not shown). Although there is no proof that the TKO protein purified from C-33A cells is the same activity which is present in other human cancer cell lines, these results suggest that a common mechanism which can inhibit IFN- $\alpha$-induced gene expression may be present in several types of transformed cells.

Thus, TKO appears to be a specific inhibitor of transcription factors involved in IFN signaling and induction of IFN- $\beta$ gene expression. It is interesting to note that the IRF proteins have also been implicated as promoters and/or repressors of cell growth $(18,46)$. Attempts to obtain cDNA clones corresponding to the $19-\mathrm{kDa}$ protein are being made. Experiments that permit us to manipulate the expression of TKO will allow us to address some questions concerning the role of E6 and E7, E1A, and phorbol esters in modulation of IFN- $\alpha$-induced gene expression and how these proteins and TKO might alter the effects of IFN- $\alpha$ on cell growth and transformation.

\section{ACKNOWLEDGMENTS}

Richard Pine generously provided the vector for in vitro translation of IRF-1, T. Taniguchi provided both IRF-1 and IRF-2 vectors, J. E. Darnell provided the $113-\mathrm{kDa}$ cDNA, and D. Levy provided the vector for in vitro translation of the $48 \mathrm{kDa}$ y protein. We thank D. Finbloom, P. Howley, and K. Munger for their critical reading of the manuscript.

M.D. was supported by a Schrödinger fellowship from the Fonds zur Förderung der wissenschaftlichen Forschung from Austria.

\section{REFERENCES}

1. Ackrill, A. M., G. R. Foster, C. D. Laxton, D. M. Flavell, G. R. Stark, and I. M. Kerr. 1991. Inhibition of the cellular response to interferons by the products of the adenovirus type 5 E1A oncogene. Nucleic Acids Res. 19:4387-4393.

2. Bandyopadhyay, S. K., D. V. R. Kalvakolanu, and G. C. Sen. 1990. Gene induction by interferons: functional complementation between trans-acting factors induced by alpha interferon and gamma interferon. Mol. Cell. Biol. 10:5055-5063.

3. Borrelli, E., R. Hen, and P. Chambon. 1984. Adenovirus 2 E1A products repress enhancer-induced stimulation of transcription. Nature (London) 312:608-612.

4. Colamonici, O. R., P. Domanski, L. C. Plantanias, and M. O. Diaz. 1992. Correlation between interferon (IFN) $\alpha$ resistance and deletion of the IFN $\alpha / \beta$ genes in acute leukemia cell lines suggests selection against the IFN system. Blood 80:744-749.

5. Dale, T. C., A. M. Ali Imam, I. M. Kerr, and G. R. Stark. 1989. Rapid activation by interferon $\alpha$ of a latent DNA-binding protein present in the cytoplasm of untreated cells. Proc. Natl. Acad. Sci. USA 86:1203-1207.

6. David, M., and A. C. Larner. 1992. Activation of transcription factors by interferon alpha in a cell free system. Science 257:813-815.

7. David, M., G. Romero, Z. Zhang, J. E. Dixon, and A. C. Larner. 1993. In vitro activation of the transcription factor ISGF3 by IFN $\alpha$ involves a membrane associated tyrosine phosphatase and kinase. J. Biol. Chem. 268:6593-6599.

8. Driggers, P. H., D. L. Ennist, S. L. Gleason, M. Wai-Han, M. S Marks, B.-Z. Levi, J. R. Flanagan, E. Appella, and K. Ozato. 1990. An interferon $\gamma$-regulated protein that binds the interferon-inducible enhancer element of major histocompatibility class 1 genes. Proc. Natl. Acad. Sci. USA 87:3743-3747.

9. Figge, J., T. Webster, T. F. Smith, and E. Paucha. 1988. Prediction of similar transforming regions in simian virus 40 large T, adenovirus E1A, and myc oncoproteins. J. Virol. 62:1814-1818.

10. Foster, G. R., A. M. Ackrill, R. D. Goldin, I. M. Kerr, H. C. Thomas, and G. R. Stark. 1991. Expression of the terminal protein region of hepatitis $\mathrm{B}$ virus inhibits cellular responses to 
interferons $\alpha$ and $\gamma$ and double-stranded RNA. Proc. Natl. Acad. Sci. USA 88:2888-2892.

11. Fu, X.-Y. 1992. A transcription factor with $\mathrm{SH} 2$ and $\mathrm{SH} 3$ domains is directly activated by an interferon- $\alpha$ induced cytoplasmic protein tyrosine kinase(s). Cell 70:323-335.

12. Fu, X.-Y., D. S. Kessler, S. A. Veals, D. E. Levy, and J. E. Darnell, Jr. 1990. ISGF-3, the transcriptional activator induced by IFN- $\alpha$, consists of multiple interacting polypeptide chains. Proc. Natl. Acad. Sci. USA 87:8555-8559.

13. Fu, X.-Y., C. Schindler, T. Improta, R. Aebersold, and J. E. Darnell, Jr. 1992. The proteins of ISGF-3, the interferon $\alpha$-induced transcriptional activator, define a gene family involved in signal transduction. Proc. Natl. Acad. Sci. USA 89:7840-7843.

14. Gutch, M., and N. C. Reich. 1991. Response of the interferon signal transduction pathway by the adenovirus E1A oncogene. Proc. Natl. Acad. Sci. USA 88:7913-7917.

15. Gutch, M. G., C. Daly, and N. C. Reich. 1992. Tyrosine phosphorylation is required for activation of an $\alpha$ interferonstimulated transcription factor. Proc. Natl. Acad. Sci. USA 89:11411-11415.

16. Hager, D. A., and R. R. Burgess. 1980. Elution of proteins from sodium dodecyl sulfate-polyacrylamide gels, removal of sodium dodecyl sulfate, and renaturation of enzymatic activity: results with sigma subunit of Escherichia coli RNA polymerase, wheat germ DNA topoisomerase and other enzymes. Anal. Biochem. 109:76-86.

17. Harada, H., T. Fujita, M. Miyamoto, Y. Kimura, M. Maruyama, A. Furia, T. Miyata, and T. Taniguchi. 1989. Structurally similar but functionally distinct factors, IRF-1 and IRF-2, bind to the same regulatory elements of IFN and IFN-inducible genes. Cell 58:729-739.

18. Harada, H., M. Kitagawa, N. Tanaka, H. Yamamoto, K. Harada, M. Ishihara, and T. Taniguchi. 1993. Anti-oncogenic and oncogenic potentials of interferon regulatory factors- 1 and -2 . Science 259:971-974.

19. Harlow, E., P. Whyte, B. R. Franza, and C. Schley. 1986. Association of adenovirus early region 1A proteins with cellular polypeptides. Mol. Cell. Biol. 6:1579-1589.

20. Igarashi, K., M. David, D. S. Finbloom, and A. C. Larner. 1993. In vitro activation of the transcription factor gamma interferon activation factor by gamma interferon: evidence for a tyrosine phosphatase/kinase signaling cascade. Mol. Cell. Biol. 13:1634 1640 .

21. Igarashi, K., M. David, A. C. Larner, and D. S. Finbloom. 1993. In vitro activation of a transcription factor by gamma interferon requires a membrane-associated tyrosine kinase and is mimicked by vanadate. Mol. Cell. Biol. 13:3984-3989.

22. Kalvakolanu, D. V. R., S. K. Bandyopadhyay, M. L. Harter, and G. C. Sen. 1991. Inhibition of interferon-inducible gene expression by adenovirus E1A proteins: block in transcriptional complex formation. Proc. Natl. Acad. Sci. USA 88:7459-7463.

23. Kanda, T., et al. 1992. Independent association of antibodies against human papillomavirus type $16 \mathrm{E} 1 / \mathrm{E} 4$ and E7 proteins with cervical cancer. Virology 190:724-732.

24. Larner, A. C., E. F. Petricoin, Y. Nakagawa, and D. S. Finbloom. 1993. IL-4 attenuates the transcriptional activation of both IFN $\alpha$ and IFN $\gamma$ induced cellular gene expression in monocytes and monocytic cell lines. J. Immunol. 150:1944 1950.

25. Levy, D. E., D. S. Kessler, R. Pine, N. Reich, and J. E. Darnell. 1988. Interferon-induced nuclear factors that bind a shared promoter element correlate with positive and negative transcriptional control. Genes Dev. 2:383-393.

26. Levy, D. E., D. J. Lew, D. S. Kessler, and J. E. Darnell. 1990. Synergistic interaction between interferon- $\alpha$ and interferon- $\gamma$ through induced synthesis of one subunit of the transcription factor ISGF3. EMBO J. 9:1105-1111.

27. Miyamoto, M., T. Fujita, Y. Kimura, M. Maruyama, H. Harada, Y. Sudo, T. Miyata, and T. Taniguchi. 1988. Regulated expression of a gene encoding a nuclear factor, IRF-1, that specifically binds to IFN- $\beta$ gene regulatory elements. Cell 54:903-913.

28. Münger, K., M. Scheffner, J. M. Huibregtse, and P. M. Howley. 1992. Interactions of HPV E6 and E7 with tumour suppresso gene products. Cancer Surv. 12:197-217.

29. Nelson, N., M. S. Marks, P. H. Driggers, and K. Ozato. 1993. Interferon consensus sequence-binding protein, a member of the interferon regulatory factor family, suppresses interferoninduced gene transcription. Mol. Cell. Biol. 13:588-599.

30. Pearse, R. N., R. Feinman, K. Shuai, J. E. Darnell, Jr., and J. V. Ravetch. 1993. Interferon $\gamma$-induced transcription of the highaffinity Fc receptor for IgG requires assembly of a complex that includes the 91-kDa subunit of transcription factor ISGF3. Proc. Natl. Acad. Sci. USA 90:4314-4318.

31. Perez, C., J. Wietzerbin, and P. D. Benech. 1993. Two cis-DNA elements involved in myeloid-cell-specific expression and gamma interferon (IFN- $\gamma$ ) activation of the human high-affinity Fcy receptor gene: a novel IFN regulatory mechanism. Mol. Cell. Biol. 13:2182-2192.

32. Petricoin, E. F., R. H. Hackett, H. Akai, K. Igarashi, D. S. Finbloom, and A. C. Larner. 1992. Modulation of interferon signaling in human fibroblasts by phorbol esters. Mol. Cell. Biol. 12:4486-4495.

33. Phelps, W. C., C. L. Yee, K. Münger, and P. M. Howley. 1988. The human papillomavirus type 16 E7 gene encodes transactivation and transformation functions similar to adenovirus Ela. Cell 53:539-547.

34. Pine, R., T. Decker, D. S. Kessler, D. E. Levy, and J. E. Darnell, Jr. 1990. Purification and cloning of interferon-stimulated gene factor 2 (ISGF2): ISGF2 (IRF-1) can bind to the promoters of both beta interferon- and interferon-stimulated genes but is not a primary transcriptional activator of either. Mol. Cell. Biol. 10:2448-2457.

35. Riley, T. E., A. Follin, N. C. Jones, and P. S. Jat. 1990. Maintenance of cellular proliferation by adenovirus early region $1 \mathrm{~A}$ in fibroblasts conditionally immortalized by using simian virus 40 large $\mathrm{T}$ antigen requires conserved region 1 . Mol. Cell. Biol. 10:6664-6673.

36. Rochette-Egly, C., C. Fromental, and P. Chambon. 1990. General repression of enhanson activity by adenovirus-2 E1A proteins. Genes Dev. 4:137-150.

37. Scheffner, M., B. A. Werness, J. M. Huibregtse, A. J. Levine, and P. M. Howley. 1990. The E6 oncoprotein encoded by human papillomavirus types 16 and 18 promotes the degradation of $\mathrm{p} 53$. Cell 63:1129-1136.

38. Schindler, C., X.-Y. Fu, T. Improta, R. Aebersold, and J. E. Darnell, Jr. 1992. Proteins of transcription factor ISGF-3: one gene encodes the 91 - and $84-\mathrm{kDa}$ ISGF-3 proteins that are activated by interferon $\alpha$. Proc. Natl. Acad. Sci. USA 89:78367839.

39. Schindler, C., K. Shuai, V. R. Prezioso, and J. E. Darnell, Jr. 1992. Interferon-dependent tyrosine phosphorylation of a latent transcription factor. Science 257:809-813.

40. Stein, R. W., and E. B. Ziff. 1987. Repression of insulin gene expression by adenovirus type 5 Ela proteins. Mol. Cell. Biol. 7:1164-1170.

41. Veals, S. A., T. Santa Maria, and D. E. Levy. 1993. Two domains of ISGF3 $\gamma$ that mediate protein-DNA and proteinprotein interactions during transcription factor assembly contribute to DNA-binding specificity. Mol. Cell. Biol. 13:196206

42. Veals, S. A., C. Schindler, D. Leonard, X.-Y. Fu, R. Aebersold, J. E. Darnell, Jr., and D. E. Levy. 1992. Subunit of an alphainterferon-responsive transcription factor is related to interferon regulatory factor and $m y b$ families of DNA-binding proteins. Mol. Cell. Biol. 12:3315-3324.

43. Velazquez, L., M. Fellous, G. R. Stark, and S. Pellegrini. 1992. A protein tyrosine kinase in the interferon $\alpha / \beta$ signaling pathway. Cell 70:313-322.

44. Velchich, A., and E. Ziff. 1985. Adenovirus E1A proteins repress transcription from the SV40 early promoter. Cell 40: $705-716$.

45. Wang, H.-G., Y. Rikitake, Y. Corrigan, P. Yaciuk, S. E. Abraham, B. Zerler, and E. Moran. 1993. Identification of specific adenovirus E1A N-terminal residues critical to the binding of cellular proteins and to the control of cell growth. J. Virol. 67:476-488. 
46. Willman, C. L., et al. 1993. Deletion of IRF-1, mapping to chromosome 5q31.1, in human leukemia and preleukemia myelodysplasia. Science 259:968-971.

47. Wilson, K. C., and D. S. Finbloom. 1992. Interferon $\gamma$ rapidly induces in human monocytes a DNA-binding factor that recognizes the $\gamma$ response region within the promoter of the gene for the high-affinity Fcy receptor. Proc. Natl. Acad. Sci. USA 89:11964-11968.
48. Yaciuk, P., M. C. Carter, J. M. Pipas, and E. Moran. 1991. Simian virus 40 large-T antigen expresses a biological activity complementary to the p300-associated transforming function of the adenovirus E1A gene products. Mol. Cell. Biol. 11:21162124.

49. Yee, S., and P. E. Branton. 1985. Detection of cellular proteins associated with human adenovirus type 5 early region E1A polypeptides. Virology 147:142-153. 